\title{
4 Education and gender in Japan and Norway from historical perspective
}

\author{
Ryoko Kodama
}

\section{Education and gender}

Although gender was known as a concept, its introduction into Japanese educational research did not begin until the mid-1980s. What was the background of this? Was the change unique to Japan or was it global? Focusing on Norway and Japan, this study examines these questions from a comparative historical perspective.

In comparisons of international gender gaps, the World Economic Forum's global gender gap index ranking in four subsections - economics, education, health and politics - comes to the fore. Japan ranks extremely low on the index and in recent years, has become notorious for gender gaps in various areas. Among the 156 countries indexed, in 2021, Japan ranked 120th. Always in the top group, in 2021, Norway ranked second. In stark contrast among the four subsections, Norway has a particularly high ranking in economics and politics, while Japan has a high ranking in health. The most interesting subsection is the education index, however, because Japan has paid little attention to its 92nd ranking. True, Japan ranks higher in education than in economics and politics but still below the global average. In rates of literacy and primary education enrolment, Japan ranks first globally, having achieved gender equality. Thus, its 92nd ranking in education can be attributed to its secondary and tertiary enrolment rates 129 th and 110th, respectively. In another stark contrast, Norway ranks first in both secondary and higher education (World Economic Forum, 2021).

Historically, both countries' gender-equal educational systems began at about the same time, shortly after the Second World War. So why are present rankings so different? Possible causes of higher education's gender gap in Japan include the hidden curriculum in school education, gender tracing in education, family members' gender-role awareness and sociocultural attitudes towards women. Despite various causes, Japan's educational gender gap is most pronounced in higher education, evidently from a variety of causes.

Therefore, this paper analysed factors that led to Japan's higher education gender gap, specifically, changes in education after the Second World 
War and in political and social trends during the 1970s and 1980s. The method employed was a comparative historical sociology approach. By comparing statistical data - mainly from government publications on education after the Second World War - we first clarified differences between Japan and Norway from a gender perspective.

\section{Higher education at present}

As for the gender gap in higher education enrolment rates, differences between European countries and Japan are illustrated in Figure 4.1, at which Japanese people are very surprised. They expect more men than women to be enrolled in higher education, so the reverse gap in several Western countries comes as a surprise.

Among many Western nations, percentages of women entering higher education are significantly higher than in Japan. In all Nordic countries, for instance, more women than men graduate from higher education, and only in Japan, Korea and Germany are men more likely to enter higher education. ${ }^{1}$ Figure 4.1 In Norway, more female students and, in Japan, more male students enrol in higher education. However, we should pay attention to the historical background behind these differences.

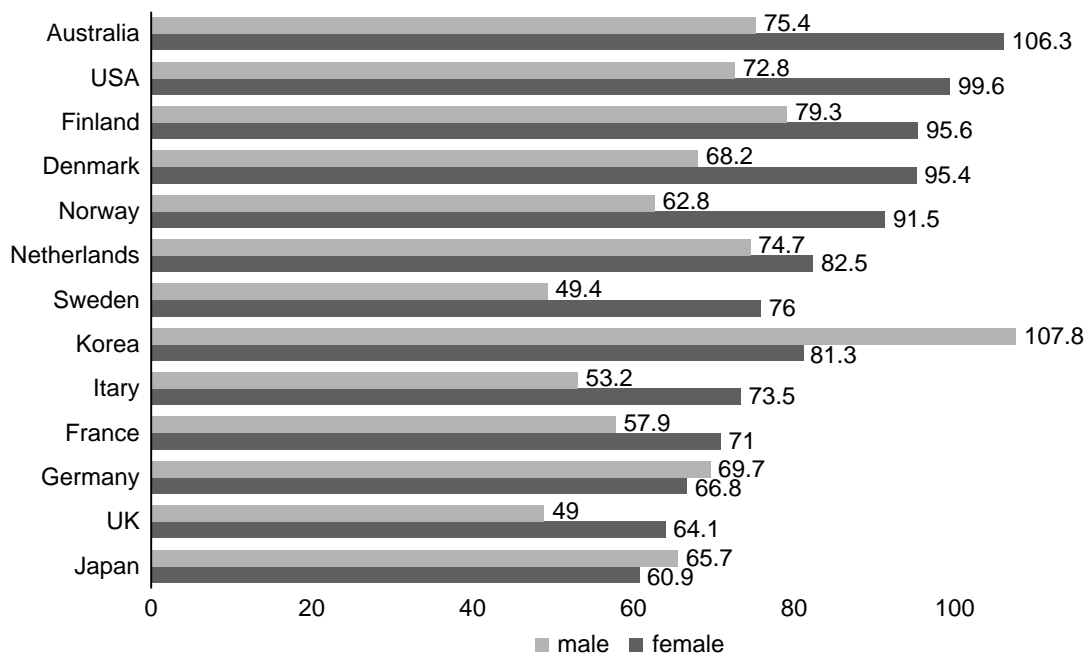

Figure 4.1 International comparison of higher education enrolment ratios.

Note. Source: Gender Equality Bureau, Cabinet Office (2018) Danjokyodosankaku-hakusyo 2018 [The white paper on gender equality 2018]. [Report]. p. 92. 


\section{Began at the same time but in different ways}

Both Japan and Norway established educational gender equality in the mid20th century, with men of both countries initially more likely to attend higher education than women. From a gender perspective, the two countries' current educational systems have their origins in mid-20th-century educational reforms, but despite similar timing, social changes magnified their small initial differences. In Norway, the School Act (Lov om Folkeskolen) was implemented in 1959 , providing nine years of compulsory education and the same curriculum for men and women. In the mid-1980s, the number of female students began to exceed that of males.

In Japan, gender issues in the educational system changed significantly in 1945. According to previous studies, before the Second World War, men and women could study together at pre-school and primary levels, but in secondary education and above, men and women were separated (Hashimoto, 1992; Hirose, 1982; Koyama, 1995). Certainly, expanding higher education opportunities and improving secondary education for women were discussed after the First World War. In practice, however, women's enrolment, with a few exceptions, remained restricted during the 1920 s, and secondary education was only partially reworked despite establishment of public and private vocational schools for women. Until the end of the Second World War, the gender-separated school system was maintained at the secondary level, and women had a lower level of education than men (Koyama, 1995, p. 6). As a defeated nation after the Second World War, Japan initiated gender equality in all systems, including enactment of a new democratic constitution. The educational system was no exception. Post-Second World War reforms were driven by the Ministry of Education, the Education Reform Commission and the Civil Information and Education Section of the occupation forces organised with democratic and liberal principles by the United States (US). Democracy in education stressed equal treatment and equal opportunities for all students, thus promoting co-education in secondary and higher education.

However, a Japanese system in which both men and women could receive the same level of secondary education was created, but in addition to coeducational schools, separate secondary schools for men and women remained. Women were allowed to attend universities, but new universities for women only were also established, thus mixing co-educational and gender-separate schools. Japanese post-war educational reform emphasised the need to promote women's education, mainly from the perspective that education was necessary for women to play an important role in society as wives and mothers (Hirose, 1982, p. 64). Furthermore, universities and junior colleges were established. In Japan's post-war educational reform, various new forms of higher education systems were created because of the previous higher education system's multiplicity. Many of the new schools lacked teachers with the necessary career experience to be recognised as 
university faculty. Post-war educational reform called for higher education's expansion, but many pre-war institutions of tertiary education did not meet conditions for recognition as universities. Some were temporarily recognised as junior colleges - partly in response to the initial expansion of community colleges in the US - and afterwards, establishment of junior colleges was approved.

In addition to four-year universities, two- and three-year junior colleges are now recognised as higher education institutions. Initially, similarly to four-year universities, more male than female students attended junior colleges. Not until the 1960s did the number of female students surpass that of males (Katayama \& Yonekawa, 1993, p. 79).

Overall, educational reform that included establishment of women's university and junior college systems had significant effects on higher education's gender balance in post-war Japan.

\section{Increase in the percentage of female students in higher education}

University enrolment rates in both Norway and Japan rose sharply in the 20th century's latter half, but examination of those rates by gender reveals highly contrasting changes, as shown in Figures 4.2 and 4.3, respectively. In Norway, education was reformed after the Second World War based on gender equality, but then, more men than women went to university, and this trend continued until the 1970s. In the 1980s, however, the ratio of men to women reversed and has continued to widen. As Figure 4.1 shows, many European countries mirror this phenomenon.

But what about Japan? Similar to Figure 4.2, Figure 4.3 shows differences in numbers of male and female students enrolled in Japanese universities during the same period. Although the enrolment rate at universities expanded during the 1970s and 1980s, gender reversal did not occur in Japan. The percentage of men in higher education expanded significantly in the 1970s, and in the 1980s, the gender gap widened. The percentage of women attending university finally began to rise sharply during the 1990s, narrowing but not reversing the gender gap.

Why does such a difference exist between Norway and Japan? Why does the number of Japanese women in higher education not exceed that of men, as in Western countries? Several reasons might explain why this trend differs in the two countries differ. One is the Japanese education system that allows segregation by gender. Although various systems in post-war Japan supposedly aimed at a gender-equal society, the process actually created a unique school system designed for women but left the existing malefavouring university system untouched. One of the most notable womenonly school systems is the Japanese junior college system. Although many women attended them, they were not included in Figure 4.3's statistics. 


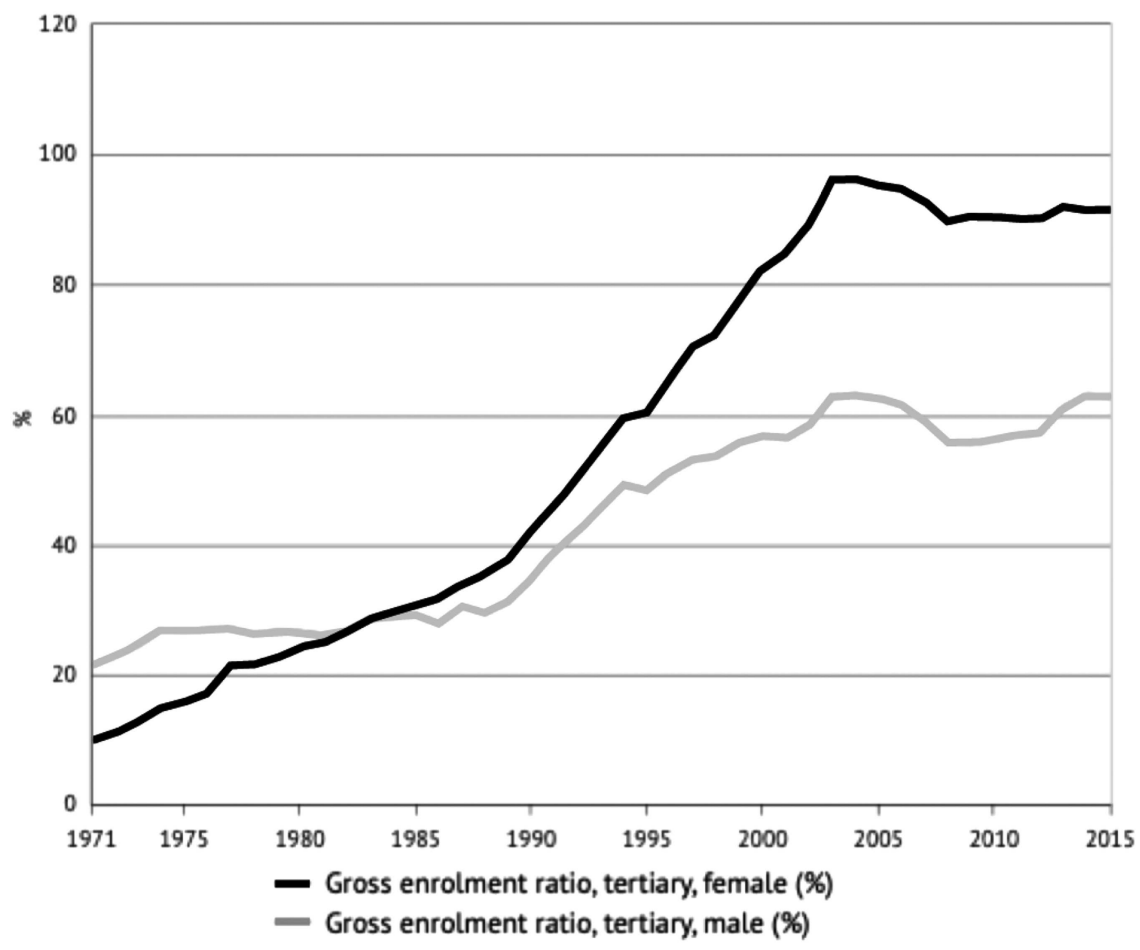

Figure 4.2 Gender differences in university enrolment rates in Norway (1971-2020). Adapted from Source: World Bank EdStats, accessed 15 Dec. 2020, https://datacatalog.worldbank. org/dataset/education-statistics.

\section{Women's junior colleges in Japan}

Figure 4.4 shows the post-war trend of higher education enrolment rates in Japan, including both universities and junior colleges. Unlike Figures 4.3, which show that the gap between men and women's enrolment rates has not been bridged, in Figure 4.4, the rates are reversed. In the mid-1980s, more women began enrolling in higher education than men, and with this, the phenomenon reversed. During that period, the same trend was also apparent in Norway.

The key to this reversal is the increase in the number of women attending junior colleges, which accounts for large part of women's participation in higher education. In other words, from the 1970s to the 1990s, the majority of women in higher education attended junior colleges in Japan. Conversely, the number of men attending junior colleges has remained consistently low. However, Figure 4.4 shows that if we include both universities and junior colleges in the statistics, more Japanese women than 


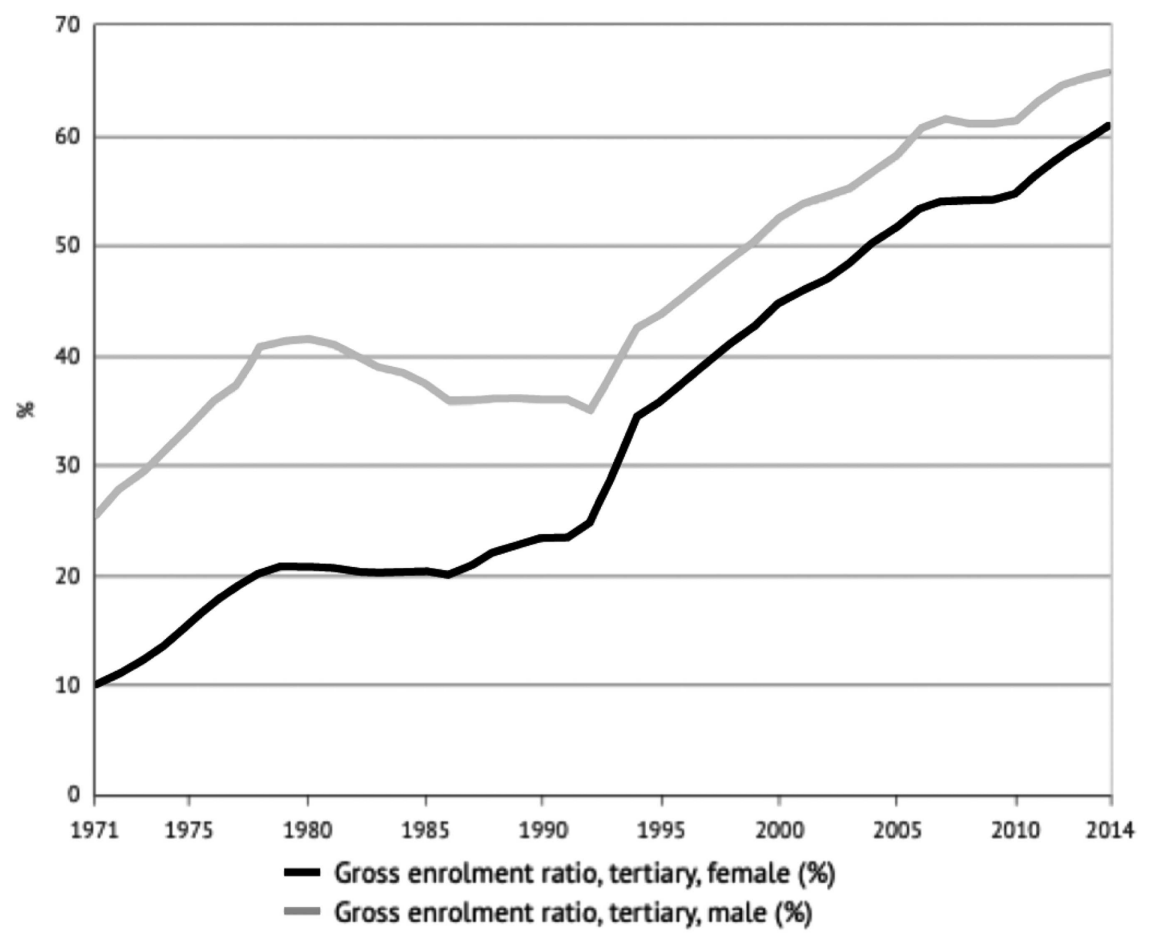

Figure 4.3 Gender differences in university enrolment rates in Japan (1971-2020).

Adapted from Source: World Bank EdStats, accessed 15 Dec. 2020, https://datacatalog.worldbank. org/dataset/education-statistics.

men enter higher education - just as in Norway. Indeed, the ratio of female junior college students can be represented by a trapezoidal shape, rising from the late 1960s, remaining unchanged until around 2000 and then falling. During this period, many women chose junior college as the path to higher education, even if only temporarily.

Figure 4.5, which displays a shape consistent with the trapezoid - like the line of only junior college women in Figure 4.4, provides a clue as to major changes in the number of junior college students. In Figure 4.5, the trapezoidal shape represents Home Economics, which, despite some variation, has clearly been the dominant major in junior colleges. In other words, the high number of Home Economics majors supported the increased number of women's junior colleges. The same was true of universities, where many female students entered departments of humanities and Home Economics (Kodama 2014).

Among junior college students, the second most common major is education, especially early childhood and elementary education. In the 1990s, 


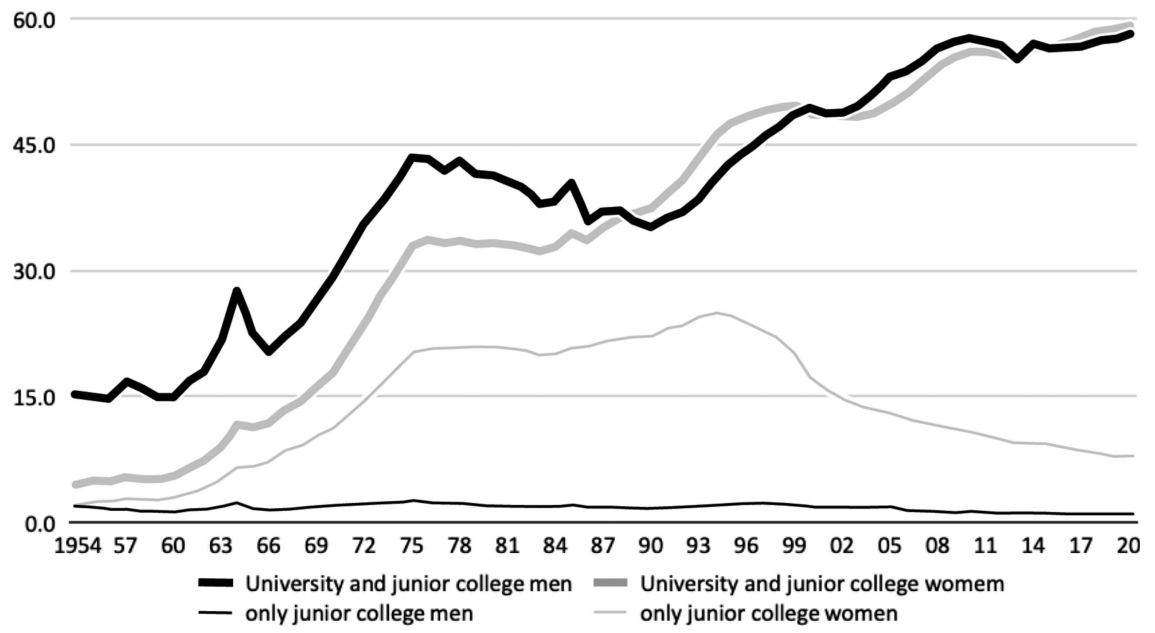

Figure 4.4 Gender differences in university and junior college enrolment rates in Japan (1954-2020).

Adapted from Source: Ministry of Education, Culture, Sports, Science and Technology. (2021). Gakko kihon chosa [Basic survey on schools], accessed 15 Dec. 2020, https://www. e-stat.go.jp/stat-search/files?page $=1 \&$ toukei $=00400001 \&$ tstat $=000001011528$.

junior colleges temporarily offered majors in humanities and social sciences, but enrolment quickly dwindled, and, again, Home Economics and early childhood education majors dominated. These majors in domestic science and childhood education might indicate that female students were expected to become housewives and mothers. In the 2000s, however, the percentage of women entering junior colleges gradually declined because women preferred university, thus leading to many junior colleges' closure and gradual replacement with universities.

Two perspectives can clarify why such a difference exists between Japanese men and women entering higher education: One is the post-war educational system, and the other is post-war Japanese society's gender consciousness. Post-war educational reform supposedly established gender equality, but establishment of women's colleges perpetuated the pre-war higher educational system. Simultaneously, junior colleges did not have the necessary conditions for higher education even though, initially, junior colleges were not created as schools for women, and more men attended them. Despite this, both women's colleges and junior colleges provided opportunities for more women to enter higher education. Importantly, despite the call for educational equality, Japanese society still held the notion that women needed education to suit their roles as housewives supporting their husbands and raising their children. As Japan's economy recovered after the Second World War, this notion gained strength. 


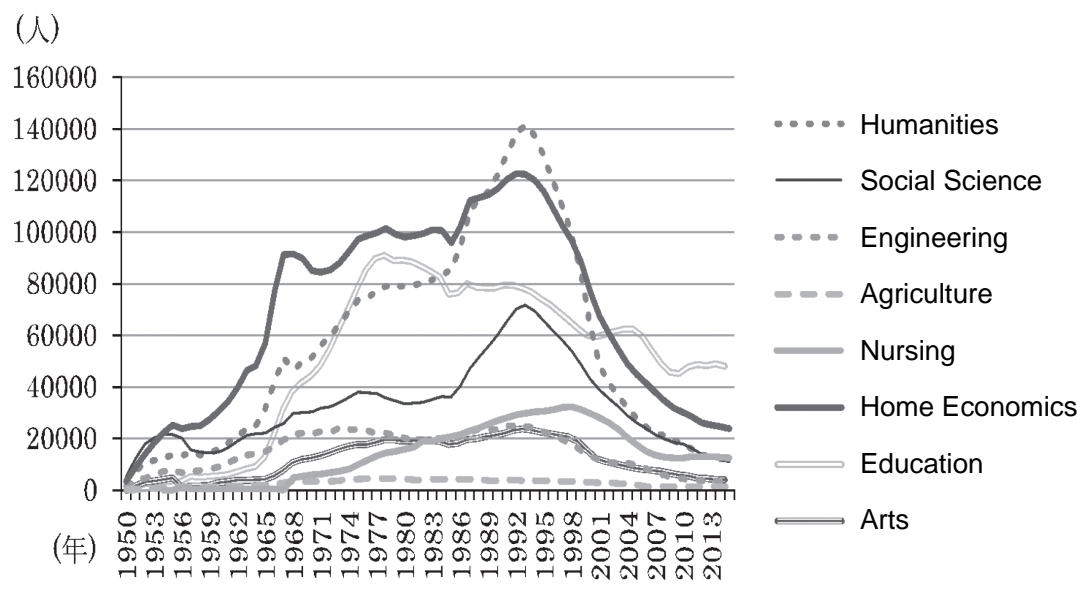

Figure 4.5 Junior college students by major in Japan (1950-2015).

Source: Suzuki, S. (2018). Sengonihon no tankidaigaku nikansuru kekyu: Kento no tameno jikikubun wo chushin ni [A study on junior college in Japan after the Second World War: Focusing on time division]. The Bulletin of the Graduate School of Education of Waseda University. Separate Volume, 25(2), p. 35.

\section{A recovering economy and the number of female workers}

As previously explained, from the late 1960s to the early 1980s, many Japanese women were attending junior colleges, majoring especially in Home Economics. Simultaneously, many women were disappearing from the job market. Figure 4.6 shows the trend in women's employment by age group, with two noteworthy points: First, from the 1960s to the 1970s, the labour force participation rate declined among women of all ages. Second, participation rates of women in their late 20 s and early 30 s declined, indicating that young women significantly disappeared from the labour scene.

As Figures 4.5 and 4.6 show, many women attended junior colleges and withdrew from the labour market during same period - linked to Japan's post-war economic recovery and changes in social structure. The mid-1950s to the early 1970s is known as Japan's period of high economic growth; the country overcame war's devastations, and average annual economic growth increased. People moved from rural to urban areas, increasing the scale of major cities such as Tokyo and Osaka. As the economy grew, workers' wages increased overall. During this period, labour unions demanded that companies pay a wage that would enable a man to provide for his wife and children. The ideal was for the husband to earn a salary and for the wife to concentrate on the home and family without having to earn a living. Workers' demands for higher wages were thus realised (Figure 4.6).

In addition to increased salaries, various institutions promoted male family members as single-income earners, and if a male worker wished, he 


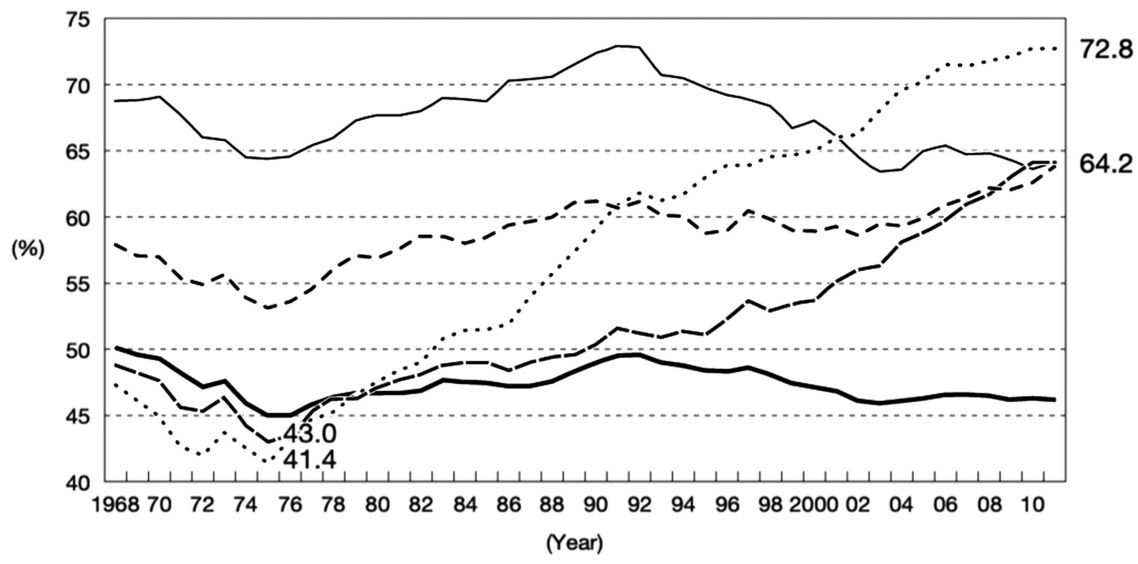

\begin{tabular}{|ll|}
\hline - All ages & 20-24 years old $\cdots \cdot 25-29$ years old \\
\hline$--30-34$ years old & $----35-39$ years old
\end{tabular}

(Note) 1 Figures from before 1972 do not include numbers from Okinawa.

2 Due to the affects of Great East Japan Earthquake, the figures from 2011 for Iwate, Miyagi, and Fukushima prefectures are supplementary estimates.

Source) Developed by MLIT from: MIC "Labor Force Survey"

Figure 4.6 Trend in employment rates of women by age group in Japan, 1968-2010.

Source: Ministry of Land, Infrastructure, Transport and Tourism. (2014). White paper on land, infrastructure, transport and tourism in Japan, 2014. [Report], p. 24.

was granted a special 'dependent's allowance' to support his wife and children. Furthermore, if the wife did not work, tax exemptions for dependents increased the husband's total income. In the 1970s, this system undeniably led to women's withdrawal from the labour market. When the average Japanese woman married in her early 20 s, she withdrew from the workforce in her late 20s or early 30s to give birth and care for her young children. Thus, the role of women as housekeepers and educators of children, not as breadwinners, was promoted by institutions supported by economic growth. In particular, children's education became Japanese mothers' most important task.

Figure 4.7 compares how women's (age 20-54) labour force participation rates in Japan and Norway have changed over the past 50 years.

As seen in Figures 4.6 and 4.7, the labour force participation rate of women, especially those who raised children, declined in Japan as the single male earner system developed during post-war economic reconstruction and the high-growth period of the 1970s. In contrast, during the 1970s in Norway, the female labour force participation rate increased to surpass Japan's, which had previously been higher. Earlier, the female labour force in Japan was rather higher than that in Norway, but in the mid-1970s, the 


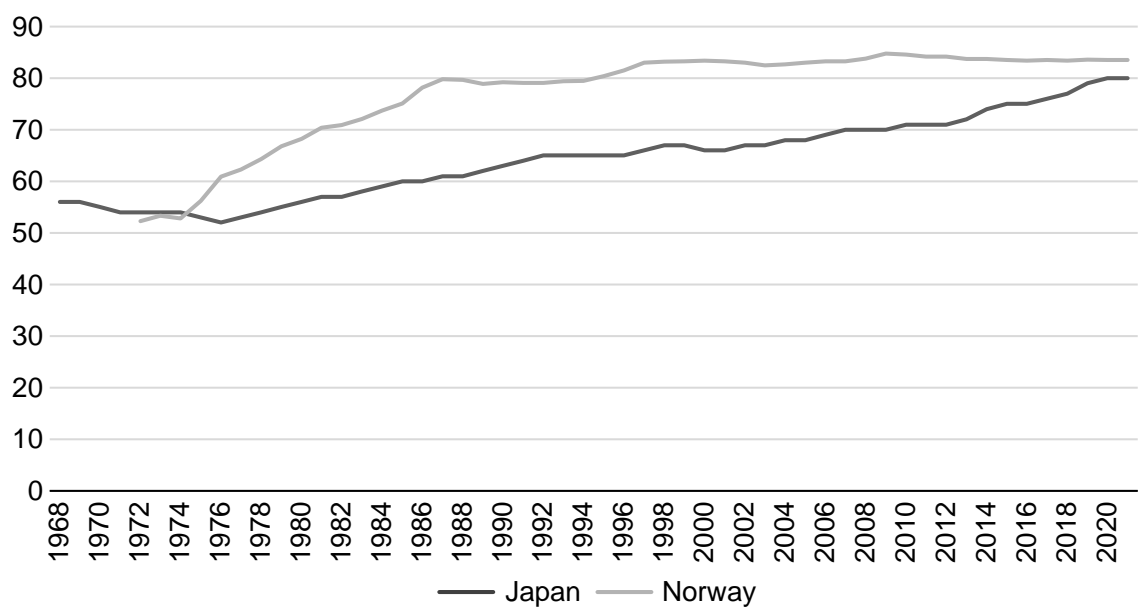

Figure 4.7 Comparison of female labour force participation rates between Japan and Norway (women aged 20-54, \%), 1968-2020.

Adapted from Source: Statistics Bureau of Japan and Statistics Norway. Statistics Bureau of Japan, Labor Force Survey, accessed 15 June 2021 https://www.stat.go.jp/english/data/ roudou/index.html. Statistics Norway, Labor Force Survey, accessed 15 June 2021 https:// www.ssb.no/en/arbeid-og-lonn/sysselsetting/statistikk/arbeidskraftundersokelsen.

two countries reversed the trend. Like Japan, Norway once strongly tended to see women's role as homemakers (Furuichi, 2019; Matsuda, 2020), but in the 1960s, Norway experienced a labour shortage and women's participation in the workforce became necessary. Significantly, Norway has been promoting gender equality laws and policies since the 1970s (Leira, 1993).

In contrast to Norway, Japan had a large working population and promoted policies based on male patriarchal roles. This explains the difference in labour force participation rates, but Figure 4.7 also shows the gap again narrowing.

\section{Economic growth and educational expansion}

Social changes and changes in the work environment subsequently affected the education system. Many families who moved to cities were not guaranteed the property they had inherited from their parents, for instance, a house. Even if they did inherit such property, they could not benefit from it as straightforwardly as those who led a life in the countryside, especially considering that they needed to build a life and support a family in the city. Consequently, they believed that education was key for a more prosperous urban life as wage earners. Entering the workforce after nine years of compulsory education was not uncommon, but at this time, parents wanted their children to attend high school for another three years. In 1950, the 
national average of students attending high school was $42.5 \%$ in Japan. By 1955 , the rate had risen by nearly $10 \%$, to $51.5 \%$. As early as 1957 , parents implored the government to build more high schools so that all children could attend high school (Ministry of Education, Culture, Sports, Science and Technology [MEXT], 1992).

These parental demands were compatible with development of national education and science policies. Japan's educational policy was also influenced by the US Education Law (1958), adopted in response to the shock of the Soviet Union's Sputnik launch. In Japan, such theories as those of manpower, educational investment and human capital have directly linked education and the economy. The 1960s witnessed a policy argument that more money should be invested in education to develop the economy. Although compulsory education was never extended beyond nine years, by the mid-1970s, over $90 \%$ of students went to high school.

Furthermore, upper secondary schools' expansion was linked to university education's subsequent expansion, and, as Japan's post-war economy recovered, the percentage of students attending its national, local government and private universities also increased. Importantly, tuition fees were not cheap. Although tuition at national and local government universities was relatively low, it was not free. Needless to say, tuition fees at private universities were much higher, but even so, the increased number of students attending universities after the Second World War was largely due to the increase in private universities.

Increased university enrolment rates also reflected that less affluent families were also pursuing higher education, sending sons to university and daughters to junior college. Even with greater opportunity for higher education, women did not need a four-year university education; two years of junior college was considered sufficient. Parents hoped their sons would get a better education and, consequently, a better job; they wanted their daughters to marry and become housewives and mothers, who needed a different education from that for a professional.

In 1959, a Japanese politician made a statement in parliament:

The role that junior colleges have played in women's education has been extremely significant. If the junior college system had not been established after the war, many women would not have had the opportunity to receive higher education. The reasons for this are the age at which women marry and the financial burden on their parents. Junior colleges are what saved women's education. (Koyama, 2008, p. 331)

Not until the 1970s, more than a decade later, did junior colleges become dominant educational institutions for women (Figure 4.4). Interestingly, the statement quoted above predicts the general status of women's education during the following two decades. 
Even though the existence of gendered junior colleges has widened universities' gender gap, they played a significant role in promoting and expanding higher education for Japanese women during the post-war period. At the same time, however, junior colleges seemed to encourage women to become housewives and mothers, thus further widening various gender gaps (e.g., economic, political) in Japanese society.

A faculty member who accepted a position at a women's junior college in the mid-1960s said in the mid-1990s, 'I have been complicit in discrimination against women and have resisted discrimination against women through my tenure at the women's junior college and through my education and research' (Yasukawa, 1996, pp. 24-5). Because junior colleges tend to prepare women to become housewives and mothers, engaging in such education seems complicit in discrimination against women. Even so, the author is a well-known researcher who has been conducting ideological research on the structure of discrimination against women in women's colleges. This author-researcher's dilemma well represents the structural problem of education in post-war Japan.

In fact, the situation of women's junior colleges changed after the 1990s, when Japan ratified the Convention on the Elimination of All Forms of Discrimination against Women in 1985, six years after the United Nations adopted the Convention in 1979. Then Japan's rapid economic growth declined, and wives' employment rates rose because their families could no longer live on their husbands' income alone. Women began to look for better jobs and better education. More female students aimed for universities instead of junior colleges, and as a result, many junior colleges closed or downsized. During this period, the gender structure hidden in Japanese education came into question, despite the system's ostensible equality. Also during this period, universities promoted gender and women's studies to provide women with empowering higher education.

\section{Current universities and their problems}

As explained above, the percentage of men who go to university is higher than that of women in Japan. However, if junior colleges are included, no gap exists between genders. Although not as high as in Europe and the US, the rate of women entering higher education is high and rising. Moreover, it must be emphasized that female students in junior colleges had a competitive motivation for learning, as pointed out by a researcher who surveyed women's junior colleges in the 1990s (Matsui, 1997). Even so, women's junior colleges earlier functioned as affirmative action, securing a place for female students to study.

Importantly, the gender gap in Japan's higher education enrolment rates disappeared during the 1980s. Also in the mid-1980s, the gender gap in higher education enrolment rates reversed in Norway. That the percentage of females in higher education exceeded that of males in both Japan and 
Norway at the same time indicates that the 1980s were an important turning point in feminism's global history. Even though female students in Japan became more motivated to study, especially at university, in the 1980s, their enrolment in women's junior colleges did not help close Japan's economic and political gender gap because many junior colleges base education on women's role as housekeepers and caregivers. Japanese junior colleges were dualistic, on the one hand, encouraging women's higher learning and on the other, keeping women in the home.

Since the 1990s, the number of junior colleges in Japan has been decreasing, and more and more female students are going to universities. In addition, women's employment rate is now increasing. It will be interesting to see how gender equality in Japan will progress in the future.

In 2018, however, a major incident came to light regarding gender in Japan's higher education. The Japan Times revealed several university medical schools to have discriminatorily manipulated university entrance examination scores in favour of men (2018). In the year following the articles' publication, female students' acceptance rate increased in many medical schools, in turn suggesting that the discrimination was real. According to the articles, medical schools wanted to avoid a doctor shortage at their universities' affiliated hospitals, believing that female doctors often resigned or took long vacations after marriage or childbirth. Japanese society was shocked to discover that such blatant discrimination against women still exists in universities. In contrast, male doctors are expected not to take long vacations, thus also revealing Japanese doctors' harsh working conditions.

Obviously, educational issues cannot be considered separately from economic, social and political issues. At first glance, education in Japan might seem to approach gender equality, but it also harbours a deep-rooted discriminatory structure that has made visible major gender discrimination in economics and society. The gender gap index does not and cannot reveal the deep-rooted structure of discrimination, thus indicating that we still have a lot of work to do.

\section{Note}

1 In particular, the high rate of male enrolment in higher education in Japan and Korea can be analysed as an Asian characteristic.

\section{References}

Furuichi, N. (2019). Norway niokeru ikuji-seisaku to danjobyodo no totatsuten: nihon tono hikaku wo toshite [Childcare policy and the reach of gender equality in Norway: A comparison with Japan]. Japanese Journal of Northern European Studies, 5, 1-11. 
Gender Equality Bureau Cabinet Office Government of Japan. (2018). Danjokyodosankaku-hakusyo 2018 [The white paper on gender equality 2018]. [Report]. https://www.gender.go.jp/about_danjo/whitepaper/h30/zentai/html/zuhyo/zuhyo0105-03.html

Hashimoto, N. (1992). Danjokyogakusei no shitekikenkyu [Historical study on coeducation system]. Otsuki-syoten.

Hirose, H. (1982). Sengo-gakuseikaikakuki niokeru danjokyogakuka nikansuru ichikosatsu [A study of coeducation in postwar Japan]. The Japanese Journal of Educational Research, 49(3), 64-72.

Japan Times. (2018, 5 September). Tokyo Medical University discriminated against female applicants by lowering entrance exam scores. https:/www.japantimes.co.jp/ news/2018/09/05/national/social-issues/men-pass-entrance-exams-women-80-japansmedical-schools-survey/

Katayama, Y., \& Yonekawa, H. (1993). Sengo-joshikyoikukai no ayumi to tankidaigaku no henyoukatei (1) [Transformation of the junior college and women's education in post war Japan (1)]. Bulletin of the Educational Research Institute of Osaka Kyoiku University, 28, 79-86.

Kodama, R. (2014). Gender to kyoiku [Gender and education]. In. H. Mimizuka (Ed.), kyoikukakusa no syakaigaku [Sociology on Educational Inequalities] (pp. 137-163). Yuhikaku Publishing.

Koyama, S. (1995). Gender to kyoiku [Gender and education]. The Japanese Journal of Educational Research, 62(3), 58-64.

Koyama, S. (2008). Tankidaigaku no joshikyoikukikanka: 1950-nendai no nibon niokeru tankidaigaku wo meguru giron/Conversion of junior colleges into women's educational institutions: The debate on junior colleges in Japan in the 1950s]. In. S. Kagawa \& S. Kawamura (Eds.), Josei to koto-kyoiku [Women and higher education] (pp. 310-336). Showado.

Leira, A. (1993). The woman-friendly welfare state?: The case of Norway and Sweden. In L. Jane (Ed.), Women and Social Policies in Europe. Edward Elgar.

Matsuda, K. (2020). Norway no hoiku-karikyuramu no kaikaku-doko: Danjokyodo nimuketa torikumi ni chakumokushite [Trends of early childhood curriculum reform in Norway. Focusing on gender equality among children]. International Journal of Early Childhood Education, 27, 123-140.

Matsui, M. (1997). Tandai ha dokohe iku [Where do junior colleges go? Gender and education]. Keiso Syobo.

Ministry of Education, Culture, Sports, Science and Technology. (2021). Gakko kihon chosa [Basic survey on schools], accessed 15 December 2020, https:/www.e-stat.go.jp/ stat-search/files?page $=1 \&$ toukei=00400001\&tstat $=000001011528$

Ministry of Education, Culture, Sports, Science and Technology. (1992). Gakusei120-nenshi [History of 120 years of school system in Japan]. Gyosei Corporation.

Ministry of Land, Infrastructure, Transport and Tourism. (2014). White paper on land, infrastructure, transport and tourism in Japan, 2014. [Report]. https:// www.mlit.go.jp/common/001113556.pdf

Statistics Bureau of Japan, Labor Force Survey, accessed 15 June 2021, https:// www.stat.go.jp/english/data/roudou/index.html

Statistics Norway, Labor Force Survey, accessed 15 June 2021, https://www.ssb.no/ en/arbeid-og-lonn/sysselsetting/statistikk/arbeidskraftundersokelsen 
Suzuki, S. (2018). Sengonihon no tankidaigaku nikansuru kekyu: Kento no tameno jikikubun wo chushin ni [A study on junior college in Japan after World War II: Focusing on time division]. The Bulletin of the Graduate School of Education of Waseda University. Separate Volume, 25(2), 33-42.

The World Bank. (2010). Educations statistics, accessed 15 December 2020, https:// datacatalog.worldbank.org/dataset/education-statistics.

World Economic Forum. (2021). The Gender Gap Report 2021. [Report]. http:// www3.weforum.org/docs/WEF_GGGR_2021.pdf

Yasukawa, E. (1996). Sengo-kotokyoiku no Gender-kozo: joshitankidaigaku deno watashi no 30-nen [Gender structure of postwar higher education: My 30 years at a women's junior college]. Quarterly Women's Education Issue, 66, 23-29. 